Annals of Plant and Soil Research 23(3): 279-285 (2021)

https://doi.org/10.47815/apsr.2021.10070

\title{
Effect of nitrogen scheduling in early and late planted medium duration rice (Oryza sativa L.)
}

\author{
KAVINDER, MANGAT RAM, V.S. HOODA, HARENDER, DEV RAJ ${ }^{1}$, KAVITA ${ }^{* 1}$ AND AKSHIT
}

Department of Agronomy, CCS Haryana Agricultural University, Hisar-125 004

Received: March, 2021: Revised accepted: April, 2021

\begin{abstract}
A field experiment on rice (Oryza sativa L.) crop was conducted at Rice Research Station, Kaul (Kaithal), India during kharif season of 2017 and 2018 to evaluate the optimum schedule of nitrogen application in the rice grown under early and late planting conditions. The treatments consisted of three timings of transplanting $\left(3^{\text {rd }}\right.$ week of June, $1^{\text {st }}$ week of July and $3^{\text {rd }}$ week of July), four levels of $N$ (90, 120,150 and 180 $\left.\mathrm{kg} \mathrm{Nha}^{-1}\right)$ and four timings of $N$ fertilizer application (1/2 at transplanting $+1 / 2$ at 21 DAT, $1 / 2$ at 21 DAT $+1 / 2$ at 42 $D A T, 1 / 3$ at transplanting $+1 / 3$ at $21 D A T+1 / 3$ at $42 D A T$ and LCC based $N$ supply) and were laid out in splitplot design with transplanting time and $N$ levels in main plots and $N$ application time in sub-plots. The growth parameters (plant height, number of tillers $/ \mathrm{m}^{2}$ and dry matter accumulation $/ \mathrm{m}^{2}$ ), yield attributing characters (number of panicles $/ \mathrm{m}^{2}$ and grains/panicle) and yield (grain and straw yield) of rice crop reduced significantly under late planting ( $3^{\text {rd }}$ week of July) as compared to that under the two earlier plantings ( $3^{\text {rd }}$ week of June and $1^{\text {st }}$ week of July) whereas the two earlier plantings were at par in respect of these parameters. The growth, yield attributes and the yield increased with every increase in $N$ application rates but the increase was significant up to $150 \mathrm{~kg} \mathrm{Nha}^{-1}$. The highest yield was $\left(7.33\right.$ tha $\left.^{-1}\right)$, however, obtained with the crop transplanted early (up to ${ }^{\text {st }}$ week of July) and supplied with $150 \mathrm{~kg} \mathrm{Nha}{ }^{-1}$. Application of $N$ in three equal splits (at 0,21 and 42 DAT or as per LCC schedule), being at par, resulted into higher yield (grain and straw) than the $N$ application in two equal splits. The net returns and B: C ratio increased appreciably with increase in $N$ application levels upto $150 \mathrm{~kg}$ Nha ${ }^{-1}$ obviously due to increase in crop yield.
\end{abstract}

Keywords: Rice, nitrogen level, split application, LCC, growth, yield, transplanting time and economics

\section{INTRODUCTION}

Rice (Oryza sativa L.) is the main food crop in India contributing around $45 \%$ to total food grains production and thus holds the key to food security. Haryana is one of the major rice producing states where the crop is grown mainly by transplanting method of crop establishment. But sometimes the transplanting is delayed due to limited availability of labour and water during the peak transplanting period resulting into reduction in the crop yield under late planting. Productivity of rice is not only controlled by genetic factors, but are also largely by environmental or management factors of which planting time and fertilization are of prime importance.Productivity of the late planted rice crop can be improved by manipulation of agronomic practices including the nutrient application schedule (dose and time of application) as the schedule of the late planted crop may differ from that of the timely or early planted crop. Rice crop is a heavy feeder of nutrients and hence higher quantities of nutrients through fertilizers are supplied to ensure higher yield. Among nutrients, $\mathrm{N}$ is the most important nutrient for rice and is one of the most yield limiting factors as it is applied in greater quantities in view of the higher crop needs and low $\mathrm{N}$ status of rice soils (Djaman et al., 2018). Moreover, synchrony of nitrogen supply with crop demand is essential in order to ensure higher nitrogen use efficiencyand crop yields.

$\mathrm{N}$ influences rice yield by playing major role in the photosynthesis, biomass accumulation, effective tillering, and spikelets formation (Jahan et al., 2020). It has been observed that yield of rice crop is decreased under late planting because of reduction in yield attributing traits viz. number of effective tillers $/ \mathrm{m}^{2}$ and grains/panicle (Ram et al., 2005). These yield attributes can be increased appreciably by supply of $\mathrm{N}$ at optimum rate and appropriate time to minimize the reduction in yield under late planting as $\mathrm{N}$ is one of the most important factors promoting growth and yield of rice crop. 
Nitrogen is usually applied to rice crop in several splits to secure proper synchrony of $\mathrm{N}$ supply with the crop demand but the number of splits, amount of $\mathrm{N}$ per split and time of application of each split may vary considerably depending upon duration of vegetative period which may differ in timely and late planted crop. Timing of $\mathrm{N}$ application can also be done with the help of leaf colour chart (LCC) which is an inexpensive, portable and easy to use tool (Nainwaland Verma, 2013).But the information on optimum dose and time of Napplication to rice crop, particularly under late planting, is very limited. Moreover, farmers have a tendency to apply more $\mathrm{N}$ fertilizer, irrespective of time of planting. The present field experiment was, therefore, conducted to find out the optimum schedule of $\mathrm{N}$ application in medium duration rice under late planted conditions.

\section{MATERIALS AND METHODS}

The present field experiment was conducted on medium duration rice cv. HKR 127 at Rice Research Station, Kaul (Kaithal) of CCS Haryana Agricultural University, Hisar during Kharifseasons of 2017 and 2018. Soil of the experimental field was loamy in texture, alkaline in reaction $(\mathrm{pH} 8.0)$, low in organic carbon $\left(4.2 \mathrm{gkg}^{-1}\right)$ and available nitrogen $\left(103 \mathrm{kgha}^{-1}\right)$, medium in available phosphorus $\left(26 \mathrm{~kg} \mathrm{P}_{2} \mathrm{O}_{5} \mathrm{ha}^{-}\right.$ $\left.{ }^{1}\right)$ and high in available potash (452 $\left.\mathrm{kg} \mathrm{K}_{2} \mathrm{O} \mathrm{ha}{ }^{-1}\right)$. The experimental treatments consisted of three transplanting schedules $\left(\mathrm{P}_{1}: 3^{\text {rd }}\right.$ week of June, $\mathrm{P}_{2}: 1^{\text {st }}$ week of July and $\mathrm{P}_{3}: 3^{\text {rd }}$ week of July), four levels of fertilizer $N\left(N_{1}: 90, N_{2}: 120, N_{3}: 150\right.$ and $\mathrm{N}_{4}: 180 \mathrm{kgha}^{-1}$ ) and four timings of fertilizer $\mathrm{N}$ application $\left(\mathrm{T}_{1}: 1 / 2\right.$ at transplanting $+1 / 2$ at 21 DAT, $T_{2}: 1 / 2$ at 21 DAT $+1 / 2$ at 42 DAT, $T_{3}: 1 / 3$ at transplanting $+1 / 3$ at 21 DAT $+1 / 3$ at 42 DAT and $\mathrm{T}_{4}$ : LCC based). The treatments were laid out in split plot design with three replications keeping planting time and $\mathrm{N}$ levels in main plots and time of $\mathrm{N}$ application in subplots.Recommended doses of phosphorus and potassium were applied through diammonium phosphate and muriate of potash, respectively. Nitrogen as urea was applied as per treatments. Plant height $(\mathrm{cm})$, number of tillers $/ \mathrm{m}^{2}$, dry matter accumulation $\left(\mathrm{g} / \mathrm{m}^{2}\right)$, panicle length, number of panicles $/ \mathrm{m}^{2}$, number of grains/panicle, 1000-grain weight, grain yield ( $\mathrm{tha}^{-1}$ ) and straw yield $\left(\right.$ tha $\left.^{-1}\right)$ were recorded at harvest. Harvest Index was calculated on the basis of grain and straw yield. The return over variable cost (Rs. ha ${ }^{1}$ ) of a treatment was estimated by subtracting its cost of cultivation (Rs.ha ${ }^{-1}$ ) from gross returns (Rs. ha ${ }^{-1}$ ) and $\mathrm{B}: \mathrm{C}$ ratio was determined by the ratio of gross returns to cost of cultivation. The data recorded during study for various parameters were statistically analyzed by the methodsof analysis of variance (ANOVA) as described by Panse and Sukhatme (1985) with thehelp of OPSTAT available at CCS HAU, Hisar, website.

\section{RESULTS AND DISCUSSION}

\section{Phenological parameters}

The data (Table 1) revealed that the crop phenological growth stages viz. panicle initiation, flowering and maturity were influenced markedly by time of transplanting. The crop transplanted earlier took more days to attain panicle initiation, flowering and maturity as compared to the crop planted very late $\left(3^{\text {rd }}\right.$ week of July) during both years (Table 1). Panicle initiation in very late ( $3^{\text {rd }}$ week of July) transplanted crop was earlier by 16-17 and 8-9 days as compared to the very early ( $3^{\text {rd }}$ week of June) and early ( $1^{\text {st }}$ week of July) transplanted crop, respectively. Similarly, very late transplanted crop took 13-14 days less to flower and mature as compared to the earliest planted crop. Sowing time primarily influences the length of vegetative period of rice with early sown rice requiring a greater number of days to accumulate the same number of degree days units compared with later planted rice Chopra et al. (2006). The rate and time of $\mathrm{N}$ application did not affect the occurrence of various phenological stages of rice. Wani et al. (2018) statedthat temperature is main driving force for development in photoperiod insensitive rice genotypes and hence no effect of $\mathrm{N}$ application schedule on phenology of rice crop in the present study may be due to the fact that the variety used was photo insensitive. 
Table 1: Phenological stages of the crop as influenced by transplanting time and schedule of $\mathrm{N}$ application

\begin{tabular}{|c|c|c|c|c|c|c|}
\hline \multirow[t]{2}{*}{ Treatment } & \multicolumn{2}{|c|}{$\begin{array}{c}\text { Days to } \\
\text { panicle initiation (DAS) }\end{array}$} & \multicolumn{2}{|c|}{$\begin{array}{c}\text { Days to } 50 \% \\
\text { flowering (DAS) }\end{array}$} & \multicolumn{2}{|c|}{$\begin{array}{c}\text { Days to } \\
\text { maturity (DAS) }\end{array}$} \\
\hline & 2017 & 2018 & 2017 & 2018 & 2017 & 2018 \\
\hline \multicolumn{7}{|c|}{ Time of transplanting } \\
\hline$P_{1}$ & 92.0 & 88.0 & 115.0 & 108.0 & 145.0 & 138.0 \\
\hline$P_{2}$ & 84.0 & 80.0 & 110.0 & 104.0 & 140.0 & 134.0 \\
\hline$P_{3}$ & 75.0 & 72.0 & 101.0 & 95.0 & 131.0 & 124.0 \\
\hline$C D(p=0.05)$ & 8.4 & 9.0 & 6.5 & 5.3 & 10.3 & 9.9 \\
\hline \multicolumn{7}{|c|}{ Levels of $N\left(\mathrm{kgha}^{-1}\right)$} \\
\hline $\mathrm{N}_{1}$ & 83.6 & 80.0 & 108.6 & 102.3 & 138.6 & 132.0 \\
\hline $\mathrm{N}_{2}$ & 83.6 & 80.0 & 108.6 & 102.3 & 138.6 & 132.0 \\
\hline $\mathrm{N}_{3}$ & 83.6 & 80.0 & 108.6 & 102.3 & 138.6 & 132.0 \\
\hline $\mathrm{N}_{4}$ & 83.9 & 80.0 & 108.9 & 102.4 & 138.9 & 132.0 \\
\hline$C D(p=0.05)$ & NS & NS & NS & NS & NS & NS \\
\hline \multicolumn{7}{|c|}{ Time of $\mathrm{N}$ application } \\
\hline $\mathrm{T}_{1}$ & 83.6 & 80.0 & 108.6 & 102.3 & 138.6 & 132.0 \\
\hline $\mathrm{T}_{2}$ & 83.6 & 80.0 & 108.6 & 102.3 & 138.6 & 132.0 \\
\hline $\mathrm{T}_{3}$ & 83.6 & 80.0 & 108.6 & 102.3 & 138.6 & 132.0 \\
\hline $\mathrm{T}_{4}$ & 83.9 & 80.0 & 108.9 & 102.4 & 138.9 & 132.0 \\
\hline$C D(p=0.05)$ & NS & NS & NS & NS & NS & NS \\
\hline
\end{tabular}

DAS: Days after sowing

\section{Growth parameters}

Late transplanting ( $3^{\text {rd }}$ week of July) of the crop reduced the plant height, number of tillers $/ \mathrm{m}^{2}$ and dry matter accumulation (at maximum vegetative growth stage of the crop) in comparison to early transplanting ( $3^{\text {rd }}$ week of June and $1^{\text {st }}$ week of July) during both the years of study (Table 2). This might be due to reduction in the vegetative period of the crop under late planting. Moreover, availability of more time for growth with optimum photoperiod and temperature for the growth of the early planted might have resulted into more nitrogen absorption for the synthesis of protoplasm responsible for rapid cell division that increase the plant in shape and size.

Table 2: Growth parameters of rice crop at maximum vegetative stage as influenced by time of transplanting and schedule of $\mathrm{N}$ application

\begin{tabular}{|c|c|c|c|c|c|c|}
\hline \multirow{2}{*}{ Treatment } & \multicolumn{2}{|c|}{ Plant height $(\mathrm{cm})$} & \multicolumn{2}{|c|}{ Number of tillers $/ \mathrm{m}^{2}$} & \multicolumn{2}{|c|}{ Dry weight of plants $\left(\mathrm{g} / \mathrm{m}^{2}\right)$} \\
\hline & 2017 & 2018 & 2017 & 2018 & 2017 & 2018 \\
\hline \multicolumn{7}{|c|}{ Time of transplanting } \\
\hline$P_{1}$ & 103.1 & 102.9 & 308 & 278 & 1157 & 1013 \\
\hline $\mathrm{P}_{2}$ & 102.2 & 102.1 & 297 & 270 & 1135 & 1000 \\
\hline$P_{3}$ & 97.5 & 95.7 & 268 & 234 & 771 & 612 \\
\hline$C D(p=0.05)$ & 4.5 & 4.1 & 13 & 9 & 56 & 67 \\
\hline \multicolumn{7}{|c|}{ Levels of $N\left(\mathrm{kgha}^{-1}\right)$} \\
\hline $\mathrm{N}_{1}$ & 88.4 & 87.8 & 260 & 233 & 861 & 713 \\
\hline $\mathrm{N}_{2}$ & 101.3 & 100.1 & 289 & 260 & 1024 & 852 \\
\hline $\mathrm{N}_{3}$ & 107.4 & 106.6 & 311 & 271 & 1103 & 963 \\
\hline $\mathrm{N}_{4}$ & 106.8 & 106.4 & 308 & 278 & 1096 & 970 \\
\hline$C D(p=0.05)$ & 5.1 & 4.7 & 15 & 10 & 64 & 77 \\
\hline \multicolumn{7}{|c|}{ Time of $\mathrm{N}$ application } \\
\hline $\mathrm{T}_{1}$ & 100.7 & 99.5 & 271 & 244 & 933 & 790 \\
\hline $\mathrm{T}_{2}$ & 100.1 & 99.9 & 285 & 255 & 1010 & 861 \\
\hline $\mathrm{T}_{3}$ & 101.8 & 100.7 & 299 & 268 & 1070 & 918 \\
\hline $\mathrm{T}_{4}$ & 101.1 & 100.8 & 306 & 275 & 1071 & 929 \\
\hline$C D(p=0.05)$ & NS & NS & 12 & 10 & 54 & 67 \\
\hline
\end{tabular}


These results are supported by the findings of Prabhakar and Reddy, (2010) and Wani et al. (2016) who found that early transplanting of rice results in better growth as compared to late transplanting. As far as different schedules of $\mathrm{N}$ application, growth parameters were highest when $\mathrm{N}$ was applied in three split doses $(0,21$ and 42 DAS) which was statistically at par with that of LCC based application. Sathiya and Ramesh (2009) also concluded that application of nitrogen in splits results in better rice growth parameters. Kumar et al. (2018) also found three split and LCC based application was better as compared to single and double $\mathrm{N}$ application.

\section{Yield attributes}

The yield attributes viz. panicle length, number of panicles $/ \mathrm{m}^{2}$ and number of grains/panicle were significantly higher with earlier schedules of transplanting ( $3^{\text {rd }}$ week of June and $1^{\text {st }}$ week of July) as compared to late transplanting (Table 3) whereas the two earlier planting schedules were at par with each other. More panicles $/ \mathrm{m}^{2}$ in earlier planted crop might be due to more tillers $/ \mathrm{m}^{2}$ and lower tiller mortalityrate under early planting than that under late planting. Moreover, the production and distribution of photosynthates might be reduced in late planted crop probably because of reduced temperature and sunshine hours coinciding with the grain filling phase of the late transplanted crop resulting in production of lesser number of grains/panicle. The results are in conformity with that of Chopra et al. (2006) and Brar et al. (2012). Time of transplanting had no significant effect on 1000-grain weight.

Number of panicles $/ \mathrm{m}^{2}$ increased significantly due to increasing level of nitrogen application up to $150 \mathrm{~kg} \mathrm{ha}^{-1}$ which might be the consequence of increase in number of tillers and dry weight at higher $\mathrm{N}$ levels. Increasing trend of panicle at the higher levels of $\mathrm{N}$ was also observed by BRRI (2002). Higher number of panicles $/ \mathrm{m}^{2}$ in treatment where $\mathrm{N}$ was applied in three equal splits (basal, 21 DAT and 42 DAT) or as per LCC schedule (Table 3 ) might be due to the fact that application of $\mathrm{N}$ in more splits ensured better availability of nitrogen to plants during the tillering period, which might have resulted into more productive tillers or panicle $/ \mathrm{m}^{2}$. The results are in agreement with those of Bera and Pramanik (2010) and Mahajan et al. (2010). However, panicle length and 1000grain weight of rice did not differ significantly due to variation in time of $\mathrm{N}$ application.

Table 3: Yield attributes of rice as influenced by transplanting time and schedule of $\mathrm{N}$ application

\begin{tabular}{|c|c|c|c|c|c|c|c|c|}
\hline \multirow[t]{2}{*}{ Treatment } & \multicolumn{2}{|c|}{$\begin{array}{c}\text { Panicle } \\
\text { length }(\mathrm{cm})\end{array}$} & \multicolumn{2}{|c|}{$\begin{array}{c}\text { No. of } \\
\text { panicles } / \mathrm{m}^{2}\end{array}$} & \multicolumn{2}{|c|}{$\begin{array}{c}\text { No. of } \\
\text { grains/ panicle }\end{array}$} & \multicolumn{2}{|c|}{$\begin{array}{l}\text { 1000-grain } \\
\text { weight }(\mathrm{g})\end{array}$} \\
\hline & 2017 & 2018 & 2017 & 2018 & 2017 & 2018 & 2017 & 2018 \\
\hline \multicolumn{9}{|c|}{ Time of transplanting } \\
\hline$P_{1}$ & 25.0 & 24.5 & 243.0 & 225.3 & 137.8 & 134.4 & 26.8 & 25.2 \\
\hline $\mathrm{P}_{2}$ & 24.5 & 24.2 & 242.9 & 222.5 & 133.7 & 136.7 & 26.6 & 25.7 \\
\hline $\mathrm{P}_{3}$ & 23.4 & 23.3 & 217.8 & 188.1 & 98.2 & 92.4 & 26.4 & 26.2 \\
\hline$C D(p=0.05)$ & 0.7 & 0.6 & 8.3 & 6.4 & 4.2 & 3.6 & NS & NS \\
\hline \multicolumn{9}{|c|}{ Levels of $N\left(\mathrm{kgha}^{-1}\right)$} \\
\hline $\mathrm{N}_{1}$ & 23.7 & 23.4 & 209.8 & 188.2 & 118.3 & 116.6 & 26.2 & 25.6 \\
\hline $\mathrm{N}_{2}$ & 24.5 & 24.1 & 234.7 & 211.1 & 123.9 & 120.8 & 26.8 & 25.2 \\
\hline $\mathrm{N}_{3}$ & 24.4 & 24.2 & 245.3 & 222.9 & 124.8 & 123.6 & 26.4 & 25.9 \\
\hline $\mathrm{N}_{4}$ & 24.6 & 24.3 & 248.6 & 225.8 & 125.8 & 123.6 & 27.0 & 26.2 \\
\hline$C D(p=0.05)$ & NS & NS & 9.6 & 7.4 & 4.8 & 4.1 & NS & NS \\
\hline \multicolumn{9}{|c|}{ Time of $\mathrm{N}$ application } \\
\hline $\mathrm{T}_{1}$ & 24.1 & 23.7 & 220.3 & 197.5 & 120.9 & 118.6 & 26.3 & 25.7 \\
\hline $\mathrm{T}_{2}$ & 24.4 & 24.1 & 232.2 & 208.8 & 124.0 & 121.6 & 26.6 & 25.7 \\
\hline $\mathrm{T}_{3}$ & 24.6 & 24.2 & 242.8 & 220.8 & 124.2 & 122.2 & 26.7 & 25.6 \\
\hline $\mathrm{T}_{4}$ & 24.2 & 24.0 & 243.1 & 220.9 & 123.7 & 122.3 & 26.9 & 25.8 \\
\hline$C D(p=0.05)$ & NS & NS & 8.2 & 7.8 & NS & NS & NS & NS \\
\hline
\end{tabular}

Number of panicles $/ \mathrm{m}^{2}$ increased significantly due to increasing level of nitrogen application up to $150 \mathrm{~kg} \mathrm{ha}^{-1}$ which might be the consequence of increase in number of tillers and dry weight at 
higher $\mathrm{N}$ levels (Table 3 ). Increasing trend of panicle at the higher levels of nitrogen was also observed by BRRI (2002). Higher number of panicles $/ \mathrm{m}^{2}$ was recorded with $\mathrm{T}_{3}$ or $\mathrm{T}_{4}$ treatment (Table 3). This was might be due to the fact that application of $\mathrm{N}$ in more splits ensured better availability of $\mathrm{N}$ to plants during the tillering period, which might have resulted into more productive tillers or panicle $/ \mathrm{m}^{2}$. The results are in agreement with those of Bera and Pramanik (2010) and Mahajan et al. (2010). However, panicle length and 1000-grain weight of rice did not differ significantly due to variation in time of $\mathrm{N}$ application. Kumar et al. (2007) also observed non-significant differences in 1000-grainweight and panicle length due to split application of $\mathrm{N}$.

\section{Yield Parameters}

All the treatments had significant effect on yield (grain and straw) of the crop but had no effect on harvest index (Table 4). Early transplanting ( $3^{\text {rd }}$ week of June or $1^{\text {st }}$ week of July) recorded significantly higher yield than late planting ( $3^{\text {rd }}$ week of July) whereas the two earlier planting schedules were at par with each other. The higher yield of early planted crop might be due to availability of more time for growth period and better photoperiod and temperature during the growth of the plants which resulted into more tillers, dry matter production, panicles and grains/panicle. The results are in general agreement with the findings of Hussain et al. (2009) and Akbar et al. (2010).

The grain and straw yield increased significantly with each increase in $\mathrm{N}$ application rate. However, the increase was significant up to $150 \mathrm{~kg} \mathrm{Nha}^{-1}$ as the yield obtained with $180 \mathrm{~kg}$ $\mathrm{Nha}^{-1}$ was at par with that of $150 \mathrm{~kg} \mathrm{~N}^{-1}$. The increase in grain and straw yield could mainly be attributed to the increase in the yield attributes viz. number of panicles $/ \mathrm{m}^{2}$ and number of grains/panicle.

Table 4: Yield and economicsof rice crop as influenced by transplanting time and schedule of $\mathrm{N}$ application

\begin{tabular}{|c|c|c|c|c|c|c|c|c|c|c|}
\hline \multirow[t]{2}{*}{ Treatment } & \multicolumn{2}{|c|}{$\begin{array}{l}\text { Grain yield } \\
\left(\text { tha }^{-1}\right)\end{array}$} & \multicolumn{2}{|c|}{$\begin{array}{l}\text { Straw yield } \\
\left(\text { tha }^{-1}\right)\end{array}$} & \multicolumn{2}{|c|}{$\begin{array}{l}\text { Harvest Index } \\
(\%)\end{array}$} & \multicolumn{2}{|c|}{$\begin{array}{l}\text { Return over variable } \\
\left.\text { cost (Rs.ha }{ }^{-1}\right)\end{array}$} & \multicolumn{2}{|c|}{$B: C$} \\
\hline & 2017 & 2018 & 2017 & 2018 & 2017 & 2018 & 2017 & 2018 & 2017 & 2018 \\
\hline \multicolumn{11}{|c|}{ Time of transplanting } \\
\hline$P_{1}$ & 7.13 & 6.80 & 8.05 & 7.62 & 47.0 & 47.2 & 38051 & 51973 & 1.53 & 1.62 \\
\hline $\mathrm{P}_{2}$ & 6.96 & 6.92 & 7.87 & 7.71 & 47.0 & 47.4 & 37552 & 56223 & 1.53 & 1.66 \\
\hline $\mathrm{P}_{3}$ & 4.56 & 4.02 & 5.13 & 4.45 & 47.0 & 47.6 & 2876 & 5632 & 1.04 & 1.06 \\
\hline$C D(p=0.05)$ & 0.21 & 0.20 & 0.26 & 0.29 & NS & NS & & & & \\
\hline \multicolumn{11}{|c|}{ Levels of $N\left(\mathrm{kgha}^{-1}\right)$} \\
\hline $\mathrm{N}_{1}$ & 5.31 & 5.06 & 6.08 & 5.57 & 46.5 & 47.8 & 13772 & 23846 & 1.19 & 1.27 \\
\hline $\mathrm{N}_{2}$ & 6.16 & 5.79 & 6.91 & 6.41 & 47.2 & 47.5 & 25738 & 36197 & 1.36 & 1.46 \\
\hline $\mathrm{N}_{3}$ & 6.63 & 6.33 & 7.40 & 7.09 & 47.3 & 47.2 & 31987 & 45029 & 1.45 & 1.54 \\
\hline $\mathrm{N}_{4}$ & 6.77 & 6.48 & 7.67 & 7.29 & 46.9 & 47.1 & 33141 & 46698 & 1.46 & 1.55 \\
\hline$C D(p=0.05)$ & 0.24 & 0.24 & 0.30 & 0.34 & NS & NS & & & & \\
\hline \multicolumn{11}{|c|}{ Time of $\mathrm{N}$ application } \\
\hline $\mathrm{T}_{1}$ & 5.78 & 5.46 & 6.47 & 6.06 & 47.1 & 47.5 & 19464 & 29827 & 1.27 & 1.35 \\
\hline $\mathrm{T}_{2}$ & 6.15 & 5.77 & 6.93 & 6.46 & 47.0 & 47.3 & 25252 & 35411 & 1.35 & 1.43 \\
\hline $\mathrm{T}_{3}$ & 6.48 & 6.21 & 7.34 & 6.88 & 46.9 & 47.5 & 30039 & 43174 & 1.42 & 1.52 \\
\hline $\mathrm{T}_{4}$ & 6.46 & 6.22 & 7.32 & 6.98 & 46.9 & 47.2 & 29883 & 43359 & 1.42 & 1.52 \\
\hline$C D(p=0.05)$ & 0.17 & 0.18 & 0.22 & 0.23 & NS & NS & & & & \\
\hline
\end{tabular}

The increase in yield attributes is associated with better availability of $\mathrm{N}$ which increased the growth and ultimately the yield attributes and yield. The results are also in conformity with that reported by Pramanik and Bera (2013), Raoet al. (2013) and Singh et al. (2017). Application of $\mathrm{N}$ in three equal splits (at 0,21 and 42 DAT or as per LCC schedule), being at par, resulted into higher yield (grain and straw) than the $\mathrm{N}$ application in two equal splits (at 0 and 21 DAT or at 21 and 42 DAT) during both the years. This might be due to more dry matter accumulation and effective tillers as application of $\mathrm{N}$ in more splits ensures more uniform availability of $\mathrm{N}$ during crucial or high demanding stage of rice plant. Fageria (2010) 
also obtained maximum grain and straw yield with application of $\mathrm{N}$ in three equal splits at sowing, active tillering and panicle initiation. Pramanik and Bera (2013) and Singh et al. (2017a) also supported similar results.

\section{Economics}

Higher return over variable cost and benefit: cost ratio (B: $\mathrm{C})$ were obtained with early planting ( $3^{\text {rd }}$ week of June and $1^{\text {st }}$ week of July) as compared to late planting (Table 4) which were obviously due to higher yield with early planting. The net returns and $\mathrm{B}$ : $\mathrm{C}$ ratio increased appreciably with increase in $\mathrm{N}$ application levels upto $150 \mathrm{~kg} \mathrm{Nha}^{-1}$ obviously due to increase in crop yield. Application of $\mathrm{N}$ in three equal splits $(0,21$ and 42 DAT or as per LCC schedule) recorded the highest returns and $B$ : C because of the higher crop yield under these treatments. These findings are in general agreement with those reported by Akbar et al. (2010).

Interaction between transplanting time and $\mathrm{N}$ application levels was found significant in respect of grain yield during both the years which revealed that grain yield of early transplanted (up to $1^{\text {st }}$ week of July) crop increased significantly up to $150 \mathrm{~kg} \mathrm{~N} \mathrm{ha}^{-1}$ but the yield of late planted ( $3^{\text {rd }}$ week of July) crop increased significantly up to $180 \mathrm{~kg} \mathrm{~N} \mathrm{ha}^{-1}$ (Table 5). Therefore, the late planted crop responded to higher dose of $N\left(180 \mathrm{~kg} \mathrm{ha}^{-1}\right)$ than the early transplanted crop $\left(150 \mathrm{~kg} \mathrm{ha}^{-1}\right)$. But the highest grain yield was obtained when the crop was transplanted early (3rd week of June or 1 st week of July) and supplied with 150 or $180 \mathrm{~kg} \mathrm{~N} \mathrm{ha}^{-1}$. Singh et al. (2017a) also reported that late planted rice responded to higher dose of $\mathrm{N}$ than the timely planted one.

Table 5: Interactive effect of transplanting time and $\mathrm{N}$ levels on grain yield (t ha $\left.{ }^{-1}\right)$ of rice crop

\begin{tabular}{|c|c|c|c|c|c|c|c|c|c|c|}
\hline \multirow{3}{*}{$\begin{array}{c}\text { Time of } \\
\text { transplanting }\end{array}$} & \multicolumn{10}{|c|}{ Levels of $\mathrm{N}$ application $\left(\mathrm{t} \mathrm{ha}^{-1}\right)$} \\
\hline & \multicolumn{5}{|c|}{2017} & \multicolumn{5}{|c|}{2018} \\
\hline & $\mathrm{N}_{1}$ & $\mathrm{~N}_{2}$ & $\mathrm{~N}_{3}$ & $\mathrm{~N}_{4}$ & Mean & $\mathrm{N}_{1}$ & $\mathrm{~N}_{2}$ & $\mathrm{~N}_{3}$ & $\mathrm{~N}_{4}$ & Mean \\
\hline$P_{1}$ & 6.40 & 7.09 & 7.51 & 7.51 & 7.13 & 6.16 & 6.73 & 7.15 & 7.17 & 6.80 \\
\hline $\mathrm{P}_{2}$ & 6.25 & 6.92 & 7.34 & 7.34 & 6.96 & 6.21 & 6.81 & 7.33 & 7.34 & 6.92 \\
\hline $\mathrm{P}_{3}$ & 3.29 & 4.47 & 5.04 & 5.46 & 4.56 & 2.79 & 3.84 & 4.51 & 4.92 & 4.02 \\
\hline Mean & 5.31 & 6.16 & 6.63 & 6.77 & & 5.05 & 5.79 & 6.33 & 6.48 & \\
\hline$C D(p=0.05)$ & & & 0.42 & & & & & 0.41 & & \\
\hline
\end{tabular}

It can be concluded from the results of the present experiment that non-scented medium duration rice crop can be transplanted up to first week of July under the agro-climatic conditions of Haryana. It should be supplied with
$150 \mathrm{~kg} \mathrm{~N} \mathrm{ha}^{-1}$ under timely transplanting (up to $1^{\text {st }}$ week of July) conditions. But if transplanting gets delayed, higher dose of $\mathrm{N}\left(180 \mathrm{~kg} \mathrm{ha}^{-1}\right)$ may be applied to obtain higher yield.

\section{REFERENCES}

Akbar, N., Iqbal, A., Khan, H.Z., Hanif, M.K. and Bashir, M.U. (2010) Effect of different sowing dates on the yield components of direct seeded fine rice.Journal of Plant Breeding and Crop Sciences 2: 312-315.

Bera, A.K. and Pramanik, K. (2010) Response of rice hybrid to different sourcrs of phosphorus and homobrassinolide under lateritic zone of West Bengal. In: Abstract of National Symposium on Sustainable rice production system under changed climate, 27th to 29th November, 2010 at
Central Rice Research Institute, Cuttack, Orissa, India. Pp- 55.

Brar, S.K., Mahala, S.S., Brara, A.S., Vashista, K.K., Neerja Sharma, B. and Buttara, G.S. (2012) Transplanting time and seedling age affect water productivity, rice yield and quality in north-west India. Agricultural Water Management 115: 217-222.

Chopra, N.K., Chopra, N., Yadav, R.N. and Nagar, K.C. (2006) Effect of transplanting dates on seed yield and quality of paddy cv. Pusa-44. Seed Research 34 (2): 218220 
Djaman, K., Mel, V.C., Ametonou, F.Y., ElNamaky, R., Diallo, M.D. and Koudahe, K. (2018) Effect of nitrogen fertilizer dose and application timing on yield and nitrogen use efficiency of irrigated hybrid rice under semi-arid conditions. Journal of Agricultural Science and Food Research 9 (2): 223.

Gautam, A.K., Kumar, D., Shivay, Y.S. and Mishra, B.N. (2008) Influence of nitrogen levels and plant spacing on growth, productivity and quality of two inbred varieties and a hybrid of aromatic rice. Archives of Agronomy and Soil Science 54(5): 515-532.

Hussain, A., Bhat, M.A., Ganai, M.A. and Hussain, T. (2009) Influence of planting dates and spacing schedules on performance of Basmati rice Pusa Sugandh-3 under Kashmir valley conditions. Environment and Ecology 27: 396-398.

Jahan, A., Islam, A., Sarkar, M.I.U., Iqbal, M., Ahmed, M.N. and Islam, M.R. (2020)Nitrogen response of two high yielding rice varieties as influenced by nitrogen levels and growing seasons. Geology, Ecology, and Landscapes: https://doi.org/10.1080/24749508.2020.17 42509

Kumar, N., Prasad, R. and Zaman, F.U. (2007) Relative response of high yielding variety and a hybrid of rice to levels and sources of nitrogen. In: Proceeding of Indian National Science Academy 73:1-6.

Kumar, P., Choudhary, S. K. and Singh, A. (2018) Effect of Nitrogen scheduling on growth, yield and economics of rice under different establishment methods. International Journal of Current Microbiology and Applied Sciences 7: 5153-5160.

Mahajan, G., Sekhon, N.K., Singh, N.N., Kaur, R. and Sidhu, A.S. (2010) Yield and nitrogen-use efficiency of aromatic rice cultivars in response to nitrogen fertilizer. Journal of New Seeds 11: 356-368.

Nainwal, K. and Verma, O. (2013) Resource conserving technologies (RCT) in ricewheat cropping system. Indian Farmer's digest 46(10): 7-9.

Panse, V.S. and Sukhatme, P. V. (1985) Statistical methods for Agricultural workers (4th Edn.) ICAR. Publication New Delhi.

Prabhakar, S.V. and Reddy, S.N. (2010) Effect of different dates of dry seeding and staggered nursery sowing on growth and yield of Kharif rice. Indian Journal of Agricultural Science 66(1): 48-50

Pramanik, K. and Bera, A.K. (2013) Effect of Seedling Age and Nitrogen Fertilizer on Growth, Chlorophyll Content, Yield and Economics of Hybrid Rice (Oryza sativaL.). International Journal of Agronomy and Plant Production 4: 34893499.

Rao, V.P., Subbaiah, G. and Sekhar, K.C. (2013) Response of rice varieties to high level nitrogen on dry matter production, yield and nitrogen uptake of rice. International Journal of Applied Biology and Pharmaceutical Technology 4(4): 216-218.

Sathiya, K. and Ramesh, T. (2009) Effect of split application of nitrogen on growth and yield of aerobic rice. Asian Journal of Experimental Biological Sciences23(1): 303-306.

Singh, A.N.,Sorokhaibam, S.,PramanikK. and Nabachandra, L. (2017a) Effect of planting time and nitrogen fertilization on yield, nutrient uptake and nitrogen use efficiency of hybrid rice under rainfed shallow land condition of North East India. International Journal of current Microbiology and Applied Science 6(11): 2112-2120.

Singh, F., Kang, J.S., Singh, A and Singh, T. (2017) Productivity of Mechanically Transplanted Rice (Oryza sativaL.) as Influenced by Time of Nitrogen Application. Indian Journal of Ecology 44(5): 569-573.

Wani, S.A., Bhat, M.A. and Bhat, M.A. (2018) An overview on the significance of sowing dates and nitrogen fertilization on growth and yield of rice. International Journal of Chemical Studies 6(2): 2640-2655.

Wani, S.A., Qayoom, S., Bhat, M.A., Lone, B.A. and Nazir, A. (2016) Influence of sowing dates and nitrogen levels on growth yield and quality of scented rice cv. Pusa Sugandh-3 in Kashmir valley. Journal of Applied and Natural Science 8(3): 17041709. 